DOI: $10.19195 / 0524-4544.325 .9$

\author{
JÓZEF KOREDCZUK \\ ORCID: 0000-0002-3471-586X \\ Uniwersytet Wrocławski \\ jozef.koredczuk@uwr.edu.pl
}

\title{
Wileński okres w życiu Iwo Jaworskiego
}

Postać Iwo Jaworskiego i jego pobyt w Wilnie w latach 1922-1939 co prawda doczekały się niedawno omówienia przez Mikołaja Tarkowskiego (olsztyńskiego badacza dziejów Wydziału Prawa i Nauk Społecznych w Wilnie) w bardzo szczegółowym przyczynku Profesor Iwo Jaworski - wileński historyk prawa $(1922-1939)^{1}$. Jednak korzystając z okazji w ramach wymiany naukowej między Uniwersytetem Wrocławskim a Uniwersytetem Edukologicznym w Wilnie i mając sposobność przejrzenia akt archiwalnych dotyczących profesora Jaworskiego, przechowywanych w Lietuvos Centrinis Valstybés Archyvas (Centralnym Państwowym Archiwum Litewskim), w niniejszym artykule pragnę odnieść się do tych aspektów wileńskiego okresu życia profesora, których nie poruszył M. Tarkowski oraz niektóre spośród przez niego omówionych uzupełnić.

Na odrodzonej w 1919 roku Wszechnicy Wileńskiej organizatorem i pierwszym dziekanem Wydziału Prawa i Nauk Społecznych był Alfons Parczewski. Jednym z problemów, z którymi musiał on w praktyce się zmierzyć i rozwiązać, była sprawa obsady personalnej poszczególnych katedr na Wydziale. Problem dotyczył także Katedry Historii Prawa na Zachodzie Europy, która pozostawała nieobsadzona, dlatego też początkowo sam A. Parczewski prowadził w wymiarze dwu godzin tygodniowo, przez cały rok, wykłady z historii prawa na zachodzie Europy, pobierając $\mathrm{z}$ tego tytułu dodatkowe wynagrodzenie ${ }^{2}$.

${ }^{1}$ M. Tarkowski, Iwo Jaworski - wileński historyk prawa, [w:] Stefan Ehrenkreutz i historycy prawa okresu dwudziestolecia międzywojennego. W 70. rocznicę śmierci ostatniego Rektora Uniwersytetu Stefana Batorego w Wilnie, red. D. Szpoper, P. Dąbrowski, Gdańsk-Olsztyn 2016, s. 79-86. Warta uwagi jest także bardzo interesująca praca tego autora Wydziat Prawa i Nauk Spotecznych Uniwersytetu Stefana Batorego w Wilnie w latach 1919-1939, Gdańsk 2015, a zwłaszcza jej punkt 2.4. Katedra Historii Prawa na Zachodzie Europy (s. 71-75).

${ }^{2}$ Lietuvos Centrinis Valstybés Archyvas (dalej: LCVA) Fond 175, Ap. 1(I)A, nr 55, k. 14. 
Prawie po trzech latach poszukiwań, w 1922 roku, znaleziono kandydata na wakującą Katedrę Historii Prawa na Zachodzie Europy ${ }^{3}$. Był nim dwudziestoczteroletni Iwo Jaworski, który rok wcześniej obronił doktorat na Uniwersytecie Jagiellońskim, syn znanego profesora Uniwersytetu Jagiellońskiego Władysława Leopolda Jaworskiego. Czy istotnie nie było innych kandydatów, czy być może nazwisko ojca sprawiło, iż to jemu właśnie powierzono prowadzenie wykładów z historii prawa na zachodzie Europy? Wieść o nominacji ojciec Iwo skwitował następującymi słowami: „Co to za uniwersytet, gdzie mój syn Iwo jest profesorem?" . Czy może był to początek kształtowania się zwyczaju, o którym wspominał Rafał Taubenschlag (a który opisał Przemysław Marcin Żukowski): „,nowozałożone uniwersytety, jak poznański i wileński - nie mając odpowiednich sił, zaczęly się zwracać o pomoc do uniwersytetu krakowskiego"s. Niezależnie od tych dywagacji w celu wyłonienia kandydata na stanowisko kierownika Katedry Historii Prawa na Zachodzie Europy powołano komisję, w której skład weszli profesorowie A. Parczewski i Stefan Ehrenkreutz oraz docent Franciszek Bossowski ${ }^{6}$.

Pracę na Uniwersytecie Stefana Batorego Iwo Jaworski faktycznie rozpoczął od października 1922 roku, obejmując Katedrę Historii Prawa na Zachodzie Europy i już w trymestrze jesiennym roku akademickiego 1922/1923 zaczął ćwiczenia, a także zorganizował seminarium, które wcześniej przy wspomnianej Katedrze nie istniało. Te fakty stały się podstawą wystąpienia rektora Uniwersytetu Stefana Batorego z pismem z dnia 12 kwietnia 1923 roku do Ministerstwa Wyznań Religijnych i Oświecenia Publicznego z wnioskiem o umieszczenie w ministerialnym wykazie stanowisk kierowniczych na rok 1923 wspomnianego seminarium ${ }^{7}$. Było to niezwykle istotnie, gdyż jak słusznie wyjaśnił P.M. Żukowski, ,,profesor na katedrze nie był jej kierownikiem”, lecz ,faktycznie był kierownikiem (dyrektorem) seminarium, odpowiedzialnego za pracę naukową i kształcenie studentów [na seminarium - J.K.] istniejącym przy tejże katedrze" ${ }^{\text {. }}$. Iwo Jaworski został zatrud-

3 W preliminarzu budżetowym Wydziału Prawa i Nauk Społecznych na rok 1922 wnioskowano o obsadę 20 katedr i dwa etaty asystentów; P.M. Żukowski, Uniwersytet nie tylko polski. Jeden z ostatnich śladów Rzeczypospolitej Jagiellońskiej - Uniwersytet Stefana Batorego w Wilnie - nadal czeka na swoja rzetelna monografie, „Res Gestae” 4, 2017, s. 215.

${ }^{4}$ Przemówienie profesora Juliusza Bardacha z okazji odnowienia jego doktoratu na Uniwersytecie Jagiellońskim w dniu 15 lutego 1999 roku - Odnowienie doktoratu profesora Juliusza Bardacha na Uniwersytecie Jagiellońskim, „Czasopismo Prawno-Historyczne” 51, 1999, z. 1-2, s. 515. Przywołując wspomniane słowa, Olga Filaszkiewicz, pisząc o wileńskich latach J. Bardacha, błędnie wywiodła, że ,profesor Leopold Jaworski wyprowadził się z Wilna i rozpoczął pracę na Uniwersytecie Jagiellońskim, a którego syn objął na USB katedrę" — O. Filaszkiewicz, Juliusz Bardach - wileńskie lata, [w:] Stefan Ehrenkreutz i historycy..., s. 88.

5 P.M. Żukowski, O obsadzaniu katedr historyczno-prawnych w Drugiej Rzeczypospolitej, [w:] Stefan Ehrenkreutz i historycy..., s. 16.

6 M. Tarkowski, Rada Wydziału Prawa i Nauk Spolecznych Uniwersytetu Stefana Batorego w Wilnie (1919-1939), „Studia Iuridica Toruniensia” 7, 2010, s. 118.

7 LCVA Fond 175, Ap. 1(I)Bb, nr 731, k. 87.

8 P.M. Żukowski, O obsadzaniu katedr ..., s. 12. 
niony jako zastępca profesora i od tego czasu aż do nadania mu w 1932 roku tytułu profesora nadzwyczajnego procedura ta co roku była powtarzana ${ }^{9}$.

Postanowieniem Prezydenta RP z dnia 15 czerwca 1932 roku Jaworski został mianowany na stanowisko profesora nadzwyczajnego historii prawa na zachodzie Europy na Wydziale Prawa i Nauk Społecznych Uniwersytetu Stefana Batorego w Wilnie ${ }^{10}$. Mianowanie to poprzedziły stosowana uchwała Rady Wydziału Prawa i Nauk Społecznych z dnia 15 czerwca 1931 roku (podjęta po zasięgnięciu opinii profesora Przemysława Dąbkowskiego oraz Stanisława Estreichera, którego Iwo Jaworski uznawał za swojego mistrza) i Senatu Uniwersytetu Stefana Batorego z dnia 19 czerwca 1931 roku $^{11}$. Do zakresu jego obowiązków Jaworskiego jako profesora, zgodnie $\mathrm{z}$ aktem mianowania, miało należeć prowadzenie badań naukowych, odbywanie wykładów i ćwiczeń z historii prawa na zachodzie Europy w zakresie potrzeb nauczania na Wydziale Prawa, kierownictwo seminarium połączonego z Katedrą Historii Prawa na Zachodzie Europy oraz inne czynności związane ze stanowiskiem profesora nadzwyczajnego. Wymiar jego obowiązków w zakresie nauczania miał wynosić 5 godzin wykładów i 2 godziny ćwiczeń tygodniowo w ciągu całego roku lub odpowiedni wymiar godzin (w ramach którego 2 godziny ćwiczeń odpowiadały 1 godzinie wykładu) ${ }^{12}$.

Iwo Jaworski był także członkiem kilkunastu komisji uniwersyteckich i wydziałowych ${ }^{13}$. Warto zwrócić uwagę na jego działalność w dwóch spośród nich: Stałej Komisji Senatu Akademickiego, która sprawowała zarząd powszechnych wykładów uniwersyteckich, oraz komisjach dyscyplinarnych — do pomocniczych sił naukowych, do spraw słuchaczów oraz do urzędników i funkcjonariuszów niższych ${ }^{14}$. Udział w pracach tych komisji świadczy o autorytecie, jakim cieszył się w środowisku Alma Mater Vilnensis oraz zaufaniu władz Uniwersytetu i Wydziału. Podobny charakter miało również powołanie go na kuratora wielu organizacji studenckich działających przy Uniwersytecie Stefana Batorego szczególnie Bratniej Pomocy Młodzieży Akademickiej, największej organizacji studenckiej na Uniwersytecie, liczącej w 1935 roku ponad 1100 członków $^{15}$.

${ }^{9}$ W roku akademickim 1922/1923 jako zastępca profesora w Katedrze Prawa Handlowego i Wekslowego został także zatrudniony Adam Chełmoński. M. Gawrońska-Garstka, Uniwersytet Stefana Batorego. Uczelnia ziem pótnocno-wschodnich Drugiej Rzeczypospolitej (1919-1939) $w$ świetle źródet, Poznań 2016, s. 86. Po wojnie, podobnie jak Iwo Jaworski, podjął on pracę we Wrocławiu.

10 Co zostało potwierdzone pismem z Ministerstwa Wyznań i Religijnych i Oświecenia Publicznego z dnia 27 czerwca 1932 roku (nr BP-9533/32) do Rektora Uniwersytetu Stefa Batorego w Wilnie; LCVA Fond 175, Ap. 1(I)Bb, nr 731, k. 2, 4.

11 Ibidem, k. 18.

12 Ibidem, k. 5.

13 Por. M. Tarkowski, Iwo Jaworski..., s. 82.

14 Rocznik Uniwersytetu Stefana Batorego w Wilnie 1938-1939, Wilno 1939, s. 124-125.

15 Sprawozdanie z działalności Wydziału Prawa i Nauk Spolecznych Uniwersytetu Stefana Batorego w Wilnie za rok akademicki 1934/35, oprac. B. Wróblewski, „Rocznik Prawniczy Wileński” 8, 1936, s. XIX; „Alma Mater Vilnensis” 1935, z. 12, s. 90. 
W uznaniu zasług dnia 17 grudnia 1938 roku Iwo Jaworski otrzymał brązowy medal „Za Długoletnią Służbę" 16 .

W 1927 roku Iwo Jaworski habilitował się. Podstawą jego habilitacji były dwie prace poświęcone przemianom ustrojowym we Francji w początkowym okresie rewolucji: Zagadnienie rządów parlamentarnych $w$ pierwszym okresie rewolucji francuskiej (Kraków 1926, 109 ss.) oraz Konstytucja Jakobińska z roku 1793 („Czasopismo Prawnicze i Ekonomiczne” 21 1923, s. 37-64) ${ }^{17}$. Warto dodać, że druga z wymienionych publikacji (Konstytucja Jakobińska) po raz drugi została wykorzystana w karierze naukowej Jaworskiego na Uniwersytecie w Wilnie. Za pierwszym razem miało to bowiem miejsce w roku 1922, kiedy jej maszynopis złożony do druku stanowił istotny element w procedurze poprzedzającej zatrudnienie Jaworskiego na Wydziale Prawa i Nauk Społecznych Uniwersytetu Stefana Batorego $\mathrm{w}$ Wilnie ${ }^{18}$. W pracy tej przedstawił on nie tylko przemiany ustrojowe w rewolucyjnej Francji i idee, które miały na nie wpływ, lecz porównał również kształtowanie się tych idei z podstawami zmian dokonującej się w tym czasie rewolucji w Rosji ${ }^{19}$. Iwo Jaworski był jednym z pierwszych — jeśli nie pierwszym — polskich historyków ustroju, który okres przemian ustrojowych i rządów jakobinów we Francji porównał z tym, co się działo w Rosji po 1917 roku, co dziś wydaje się dla wszystkich oczywiste. Wracając do sprawy jego habilitacji, należy wspomnieć, że główny referat na podstawie wspomnianych publikacji przygotowali i na posiedzeniu Rady Wydziału w dniu 17 lutego 1927 roku przedstawili Wacław Komarnicki i S. Ehrenkreutz, referat dodatkowy zaś A. Parczewski, którego wystąpienie opierało się tylko na publikacji Jaworskiego omawiającej $\mathrm{Za}$ gadnienie rzadów parlamentarnych w pierwszym okresie rewolucji Francuskiej ${ }^{20}$. Colloquium habilitacyjne wyznaczono na dzień 22 lutego 1927 roku — pytania w jego trakcie zadawali wyłącznie referenci habilitacji Iwo Jaworskiego, a trwało ono półtorej godziny. Po zakończeniu referenci wnieśli, by zwolnić Iwo Jawor-

16 LCVA Fond 175, Ap. 1(I)Bb, nr 731, k. 9-10.

17 Ibidem, k. 57-62; M. Tarkowski, Iwo Jaworski..., s. 84. Do zainteresowań rewolucyjną Francją Jaworskiego nawiązała po wojnie jego doktorantka Teresa Janasz, która początkowo miała pisać doktorat na temat Wpływ uczonych i publicystów francuskich XVIII wieku na polskie zagadnienia ustrojowe czasów Oświecenia, następnie Ustawodawstwo socjalne we Francji od XVII wieku do czasów Restauracji, by ostatecznie obronić rozprawę Praca najemna we Francji w czasach Rewolucji i I Cesarstwa (Warunki prawne). Promotor tej rozprawy, Leszek Winowski, który zastąpił zmarłego w 1959 roku Jaworskiego, po jej obronie powiedział, że praca ta „miała dwóch promotorów, z których niestety tylko jeden może być tu obecny" (czyli L. Winowski, drugi natomiast Iwo Jaworski - nie). J. Koredczuk, 60-lecie powołania katedr historyczno-prawnych na Wydziale Prawa Uniwersytetu Wrocławskiego, „Prawo” 303, 2007, s. 39.

18 M. Tarkowski, Iwo Jaworski..., s. 79.

19 D. Szpoper, M. Tarkowski, Nauczanie prawa na Uniwersytecie Stefana Batorego w Wilnie (1919-1939), [w:] Wybrane problemy nauki i nauczania prawa, red. E. Kozerska, P. Sadowski, A. Szymański, Opole 2010, s. 67.

${ }^{20}$ LCVA Fond 175, Ap. 1(I)Bb, nr 731, k. 52-62, 65, 67-68. 
skiego z odbywania wykładu habilitacyjnego, uzasadniając swój postulat tym, że w ciągu czterech lat wykazał się on umiejętnością wykładu ${ }^{21}$.

Habilitację Jaworskiego poprzedził wyjazd do Francji (od 1 listopada 1924 do 1 października 1925 roku) ${ }^{22}$. W trakcie tej podróży uczestniczył on między innymi pod kierunkiem profesora François Oliviera-Martina w pracach seminaryjnych z zakresu historii prawa francuskiego. Olivier-Martin był znanym historykiem francuskiego prawa publicznego, profesorem wydziału prawa w Paryżu, a tym czasie opublikował między innymi dwutomową Histoire de la coutume de la prévôté et vicomte de Paris (Paryż 1922-1926). Oprócz tego był on również autorem kilkunastu publikacji poświęconych początkowemu okresowi rewolucji francuskiej, a więc temu, który najbardziej interesował Iwo Jaworskiego ${ }^{23}$.

Wyjazd Jaworskiego do Francji wiązał się oczywiście z określonymi kosztami. Uchwałą Rady Wydziału z dnia 23 stycznia 1924 roku i Senatu Uniwersytetu Stefana Batorego z dnia 25 stycznia 1924 roku udzielono mu na rok akademicki 1924/1925 płatnego urlopu, na rok zaś 1925 miał on wystąpić o stypendium. Jednakże pismem Ministra Wyznań Religijnych i Oświecenia Publicznego z dnia 4 kwietnia 1924 roku odmówiono mu udzielenia płatnego urlopu, wskazując, by starał się o stypendium francuskie ${ }^{24}$. Ostatecznie na okres od 1 listopada 1924 roku do 1 kwietnia 1925 Jaworski otrzymał bezpłatny urlop. Na dalsze studia w Paryżu, od 1 października 1925 roku, na okres 10 miesięcy, otrzymał zaś 1700 zł stypendium. Warunkiem jego przyznania było przedłożenie sprawozdania o pracach prowadzonych w Paryżu ${ }^{25}$.

Działalność naukowa Iwo Jaworskiego nie była zbyt szeroka. Leszek Winowski określił go „człowiekiem bardziej słowa niż pióra”"26. Wpływ na to zapewne miał także stan zdrowia Jaworskiego, zwłaszcza choroba oczu. Jego dotychczasowy dorobek można podzielić na publikacje, które ukazały się przed i po jego habilitacji. Prace, które ukazały się drukiem po habilitacji, koncentrowały się na ogół wokół problematyki litewskiej. Na trzy spośród nich pragnę zwrócić uwagę: Zarys dziejów Wilna (Wilno 1929), który został wydany przez magistrat miasta Wilna; Przywileje miejskie na prawo niemieckie w Wielkim Księstwie Litewskim oraz nieujęte przez M. Tarkowskiego obszerne Studia nad ustrojem miast na prawie niemieckim $w$ Wielkim Księstwie Litewskim $w$ dobie Jagiellońskiej ${ }^{27}$, w których złożył podziękowania Teofilowi Emilowi Modelskiemu (w latach 1924-1930

21 Ibidem, k. 65-66.

22 Ibidem, k. 14.

23 Pod kierunkiem F. Olivier-Martina w 1937 roku studia kontynuował także Michał Sczaniecki.

${ }^{24}$ LCVA Fond 175, Ap. 1(I)Bb, nr 731, k. 80, 83.

25 Ibidem, k. 72-73, 75.

26 L. Winowski, Iwo Jaworski, [w:] Uczeni wrocławscy (1945-1979), red. J. Trzynadlowski, Wrocław 1980, s. 92.

27 Które ukazały się w „Roczniku Prawniczym Wileńskim” 5, 1931, s. 297-352. 
profesorowi Uniwersytetu Stefana Batorego, a po wojnie - podobnie jak Iwo Jaworski - Uniwersytetu Wrocławskiego) za cenne wskazówki dotyczące źródeł historii miasta Wilna ${ }^{28}$. Do zainteresowań lituanistycznych Jaworskiego nawiązywało także jego wystąpienie na Powszechnym Zjeździe Historyków Polskich w Wilnie w dniach 17-20 września 1935 roku, na którym w ramach sekcji drugiej, historii prawa, wygłosił on referat Zagadnienie feudalizmu litewskiego i zachodniego $^{29}$. Wystąpienie to i Henryka Łowmiańskiego Zagadnienie feudalizmu $w$ Wielkim Księstwie Litewskim ${ }^{30}$, także wygłoszone w sekcji drugiej, uznano za udaną próbę badań komparatystycznych, istotnych w poznaniu historycznym ${ }^{31}$.

$\mathrm{Z}$ innych publikacji Iwo Jaworskiego można wyróżnić przedmowę jego autorstwa do pracy zbiorowej wydanej z okazji jubileuszu pracy pisarskiej Mariana Zdziechowskiego (wybitny slawista, rektor Uniwersytetu Stefana Batorego) ${ }^{32}$ oraz nekrolog Michała Bobrzyńskiego opublikowany w 1936 roku w „Ateneum Wileńskim"33.

Z kierowaniem Katedrą związane było także prowadzenie proseminarium. Proseminarium historyczno-prawne dla słuchaczy I roku studiów prowadzone przez Iwo Jaworskiego, mimo wysokich wymagań wstępnych warunkujących przyjęcie na nie, cieszyło się dużą popularnością wśród studentów. Być może dlatego że, jak wspominają słuchacze jego wykładów i uczestnicy seminariów, „wykłady i seminaria prowadził bardzo żywo, miał ogromne poczucie humoru i jakiś bezpośredni i prosty stosunek do studentów"34. W roku akademickim 1934/1935 na to proseminarium zapisało się 106 osób, z czego zaledwie 69 ukończyło je, otrzymując świadectwo seminaryjne. Natomiast w roku akademickim 1936/1937 na prowadzone przez Jaworskiego proseminarium, w ramach którego odbyto 14 posiedzeń, zapisało się 104 studentów, a świadectwa seminaryjne otrzymało 62 spośród nich. W prowadzeniu proseminarium Jaworskiemu pomagał asystent Katedry ${ }^{35}$.

28 I. Jaworski, Studia nad ustrojem miast na prawie niemieckim $w$ Wielkim Księstwie Litewskim w dobie Jagiellońskiej, „Rocznik Prawniczy Wileński” 5, 1931, s. 299, przyp. 1.

29 I. Jaworski, Zagadnienie feudalizmu litewskiego i zachodniego, [w:] Pamiętnik Powszechnego Zjazdu Historyków Polskich w Wilnie 17-20 września 1935 roku, t. 1, Lwów 1936, s. 220-227; Sprawozdanie z działalności..., s. XV.

${ }^{30}$ H. Łowmiański, Zagadnienie feudalizmu w Wielkim Księstwie Litewskim, [w:] Pamiętnik Powszechnego Zjazdu Historyków Polskich w Wilnie 17-20 września 1935 roku, t. 1, Lwów 1936, s. 209-219.

31 A. Czapiuk, Spotkanie historyków w międzywojennym Wilnie. O Powszechnym Zjeździe Historyków Polskich, „Białostockie Teki Historyczne” 8, 2010, s. 161.

${ }^{32}$ I. Jaworski, Przedmowa, [w:] 50-lecie pracy pisarskiej Marjana Zdziechowskiego, Wilno 1933.

33 I. Jaworski, Michat Bobrzyński (1849-1935), „Ateneum Wileńskie” 11, 1936, s. 902-904.

34 M. Tarkowski, Iwo Jaworski..., s. 83.

35 Sprawozdanie z działalności..., s. XI; Sprawozdanie z działalności Wydziału Prawa i Nauk Społecznych Uniwersytetu Stefana Batorego w Wilnie za rok akademicki 1936/37, oprac. J. Panejko, „Rocznik Prawniczy Wileński” 9, 1938, s. 346. 
Warto dodać, że jednym z zastępców asystenta w kierowanej przez Iwo Jaworskiego Katedrze Historii Prawa na Zachodzie Europy, powołanym na to stanowisko w 1935 roku, był Wojciech Magdziak. Został on asystentem jeszcze przed ukończeniem studiów w 1937 roku i tuż przed wojną, w czerwcu 1939 roku, udało mu się obronić doktorat. Również po II wojnie światowej miał on okazję ponownie pracować pod kierunkiem Iwo Jaworskiego, będąc zatrudniony od maja do września 1956 roku jako starszy asystent w Katedrze Powszechnej Historii Państwa i Prawa we Wrocławiu ${ }^{36}$.

W latach 1935-1935 Iwo Jaworski był także zastępcą przewodniczącego (S. Ehrenkreutza) i członkiem komisji egzaminacyjnej dla studentów po I roku studiów ${ }^{37}$.

Z działalnością naukową i dydaktyczną wiązała się także działalność popularyzatorska Jaworskiego. W tym zakresie już na początku swojego pobytu w Wilnie w 1923 roku miał popularny odczyt w przedmiocie prawa w Sali Śniadeckich Uniwersytetu Stefana Batorego w ramach Towarzystwa Prawniczego im. Ignacego Daniłowicza w Wilnie (założonego dwa lata wcześniej z inicjatywy mecenasa Tadeusza Wróblewskiego, ucznia Włodzimierza Spasowicza) ${ }^{38}$. Podobny charakter miał także wygłoszony przez niego dnia 9 maja 1930 roku koreferat Praca misyjna a Eucharystia (stanowiący uzupełnienie do referatu W. Komarnickiego Praca misyjna przez Eucharystię) na Archidiecezjalnym Kongresie Eucharystycznym w Wilnie (w ramach IV Sekcji Akademickiej i dla Inteligencji) ${ }^{39}$.

W okresie jego pobytu w Wilnie miały miejsce także ważne wydarzenia w życiu osobistym Jaworskiego. Dnia 10 września 1927 roku zawarł związek małżeński z Haliną z Wardejnów, doktor nauk lekarskich, która jednak jako lekarz nie praktykowała - z powodu zawarcia małżeństwa rektor Uniwersytetu Stefana Batorego przyznał Jawroskiemu dodatek ekonomiczny ${ }^{40}$. W Wilnie też w 1929 roku urodził się jego syn Władysław Leopold (po wojnie profesor Szkoły Głównej Handlowej).

Mimo nie najlepszego zdrowia Iwo Jaworski nie nadużywał zwolnień lekarskich (być może dlatego, że miał w domu lekarza - żonę) i tylko raz nie odbył zajęć z powodu choroby. Było to dnia 19 lutego 1936 roku $^{41}$.

Wyjątkowo uroczysty charakter miał dla Jaworskiego dzień 29 maja 1930 roku - nastąpiło wówczas uroczyste wręczenie dyplomów doktora honoris causa Wydziału Prawa i Nauk Społecznych Uniwersytetu Stefana Batorego, które nadano wybitnym uczonym z okazji dziesięciolecia wskrzeszenia Uniwersytetu w Wilnie

36 Pracował on tylko „na papierze”, gdyż nie mogąc znaleźć mieszkania we Wrocławiu, faktycznie nie pojawił się w nim. J. Koredczuk, 60-lecie powołania ..., s. 22, 69.

37 LCVA Fond 175, Ap. 1(I)A, nr 805, k. 13, 15, 26-27.

38 „Rocznik Prawniczy Wileński” 4, 1930, s. 431.

39 Archidiecezjalny Kongres Eucharystyczny, Wilno 1930, s. 18.

40 LCVA Fond 175, Ap. 1(I)Bb, nr 731, k. 14, 51.

41 LCVA Fond 175, Ap. 1(I)A, nr 805, k. 25. 
i trzystapięćdziesięciolecia istnienia Wszechnicy w Wilnie. Jedną z osób, która dostąpiła tego zaszczytu, był ojciec Jaworskiego, profesor Uniwersytetu Jagiellońskiego Władysław Leopold Jaworski. Nie mógł on ze względu na stan zdrowia przybyć osobiście do Wilna, by odebrać dyplom, dlatego też w jego imieniu zrobił to jego syn. Dziekan S. Ehrenkreutz, wręczając Iwo Jaworskiemu dyplom, zwrócił się do niego słowami: „Kolego, zanieście Czcigodnemu Ojcu Waszemu, znakomitemu prawnikowi i myślicielowi serdeczne pozdrowienia i wyrazy głębokiej czci od naszego Wydziału"42. Biorąc pod uwagę stan zdrowia swojego ojca, który zmarł dnia 14 lipca 1930 roku, można się spodziewać, że Jaworski czym prędzej to uczynił, udając się do Krakowa. Równie smutną podróż do Krakowa, jak na pogrzeb swojego ojca, odbył on także niespełna pięć lat później, kiedy to jako oficjalny członek delegacji samorządu wileńskiego w dniach 17-18 maja 1935 roku uczestniczył w uroczystościach pogrzebowych w Krakowie po śmierci Józefa Piłsudskiego ${ }^{43}$.

Iwo Jaworski i jego żona Halina słynęli z gościnności i z tego, że mieli wielu przyjaciół. Zaliczał się do nich Andrzej Mycielski, przyjaciel Jaworskiego jeszcze z czasów studiów na Uniwersytecie Jagiellońskim. Mycielski był uczniem ojca Iwo, W.L. Jaworskiego, który był nie tylko jego mistrzem, ale również promotorem doktoratu. Iwo Jaworski wprowadzał nowo zatrudnionego w 1932 roku na Uniwersytecie w Wilnie i na tym samym co on Wydziale Mycielskiego w arkana życia akademickiego oraz środowiska wileńskiego ${ }^{44}$. Po II wojnie światowej obydwaj panowie znaleźli się we Wrocławiu, zostając profesorami na tutejszym Wydziale Prawa. O tym że Iwo Jaworski, mimo że nie był rodowitym wilnianinem, stał się osobą znaną w grodzie nad Wilią, świadczy fakt, że wspomina o nim w swoich Elegiach wileńskich Konstanty Ildefons Gałczyński, pisząc: „U Sztralla (vis-à-vis Poczty) schodzą się professores: Dembiński, Iwo Jaworski, Manfred Kridl, Srebrny ateńczyk" ${ }^{\prime 4}$.

Zanim podjął pracę na Uniwersytecie Stefana Batorego Iwo Jaworski służył w wojsku w 77. pułku piechoty (od 3 listopada 1918 do 5 kwietnia 1920 roku i od 10 lipca do 10 listopada 1920 roku), z tego ponad piętnaście miesięcy spędził na froncie, walcząc o wschodnią granicę Rzeczypospolitej (obsługując karabin maszynowy w pociągu pancernym ,Śmiały”). Z tego między innymi powodu ukończył studia na Wydziale Prawa Uniwersytetu Jagiellońskiego z dwuletnim opóźnieniem. Również w trakcie pracy w Wilnie jako podporucznik rezerwy kilkakrotnie odbywał

42 Uroczysta promocja doktorów honoris causa Wydziału Prawa i Nauk Społecznych Uniwersytetu Stefana Batorego w dn. 29 maja 1930 r., „Rocznik Prawniczy Wileński” 4, 1930, s. 419. Iwo Jaworski zestawił także bibliografię prac swojego ojca w pracy zbiorowej, która ukazała się po jego śmierci: Bibljografia prac Władysława Leopolda Jaworskiego, [w:] Wt. L. Jaworskiego życie i działalność, red. S. Estreicher et al., Kraków 1931, s. 167-172.

43 „Kurjer Wileński” z dnia 17 maja 1935 r., r. XII, nr 133, s. 5.

44 A. Mycielski, Chwile czasu minionego, Warszawa 2012, s. 234, 255.

45 E. Klein, J. Koredczuk, Iwo Jaworski (1898-1959), [w:] Pamięci zmartych Profesorów i Docentów Wydziału Prawa, Administracji i Ekonomii Uniwersytetu Wrocławskiego 1945-2010, red. L. Lehmann, M. Maciejewski, Wrocław 2010, s. 111. 
ćwiczenia wojskowe dla oficerów rezerwy (od 25 lipca do 5 września 1927 roku, 9-14 marca 1931 i od 18 maja do 27 czerwca 1931 roku) ${ }^{46}$. Z ćwiczeń, w których miał uczestniczyć w lipcu-sierpniu 1927 roku (w okresie poprzedzającym zawarcie przez niego związku małżeńskiego), został przez władze dziekańskie wyreklamowany ${ }^{47}$. Natomiast z ćwiczeń, na które miał stawić się dnia 3 czerwca 1931 roku (mimo że były to drugie w odstępie zaledwie trzech miesięcy jego ćwiczenia wojskowe w tym samym roku), nie udało się rektorowi Uniwersytetu Stefana Batorego go zwolnić - Jaworski musiał stawić się na nie dwa tygodnie wcześniej. Na ćwiczenia rezerwistów był najczęściej powoływany do 25 . pułku piechoty ${ }^{48}$, który stacjonował w Piotrkowie Trybunalskim, a więc dosyć daleko od Wilna.

Podczas swego pobytu w Wilnie Iwo Jaworski kilkakrotnie zmieniał miejsce zamieszkania. Tuż przed habilitacją dnia 13 grudnia 1926 roku rektor Uniwersytetu Stefana Batorego przyznał mu mieszkanie po profesorze Janie Weyssenhofie przy ul. Zamkowej $11^{49}$. Następnie na początku maja 1929 roku otrzymał mieszkanie służbowe po profesorze Juliuszu Rudnickim przy ul. Zamkowej 22 m. $1^{50}$ - nie było to mieszkanie, o które początkowo wnosił, gdyż w podaniu z dnia 18 stycznia 1929 roku prosił o przyznanie mu mieszkania przy ul. Wielkiej 24 po profesorze Marianie Hłasce ${ }^{51}$. W mieszkaniu po profesorze J. Rudnickim Iwo Jaworski mieszkał do 10 października 1932 roku, a opuszczając je, jednocześnie zrzekł się także przyznanego mu przez rektora mieszkania po profesorze Janie Otrębskim pod tym samym adresem, czyli przy ul. Zamkowej $22^{52}$. Na koniec zaś, w 1938 roku, zamieszkał przy ul. Portowej $5 \mathrm{~m}$. 14. Miał stamtąd dalej do Katedry, która mieściła się przy ul. Uniwersyteckiej $7^{53}$, niż z poprzednich miejsc zamieszkania. Ogólnie sytuacja mieszkaniowa profesorów Uniwersytetu Stefana Batorego była wyjątkowo dobra: władze uczelni od początku starały się pozyskać dla nich mieszkania, szybko doszły bowiem do wniosku, że nie zdołają ściągnąć do siebie uczonych z innych ośrodków bez oferty dużego służbowego lokum ${ }^{54}$.

46 LCVA Fond 175, Ap. 1(I)Bb, nr 731, k. 14.

47 Ibidem, k. 52-53.

48 Ibidem, k. 39-40.

49 Ibidem, k. 69.

50 Andrzej Stefan Ehrenkreutz (syn S. Ehrenkreutza) wspomina, że w budynku przy ul. Zamkowej 22, gdzie mieszkał Iwo Jaworski, znajdowała się także stancja dla uczennic zarządzana przez babcię Aleksandry Cat Mackiewicz. Jedna z pensjonariuszek tejże stancji, gdy Iwo Jaworski rozmawiał z zarządczynią, chcąc zwrócić na siebie jego uwagę, rzekomo zaszyła mu kieszenie. Po przeprowadzonym w tej sprawie dochodzeniu Jaworski miał się z nią ostatecznie ożenić. R. Mieczkowski, Andrzej Stefan Ehrenkreutz (1921-2008), „Niepodległość i Pamięć” 2009, nr 29, s. 230. Wydaje się to bardzo mało prawdopodobne, gdyż Jaworski zamieszkał przy ul. Zamkowej $22 \mathrm{w} 1929$ roku dwa lata po zawarciu związku małżeńskiego, a wcześniej mieszkał przy ul. Zamkowej 11.

${ }^{51}$ LCVA Fond 175, Ap. 1(I)Bb, nr 731, k. 44-45.

52 Ibidem, k. 29-31.

53 Rocznik Uniwersytetu..., s. 132, 152.

54 M. Przeniosło, Profesorowie wydziału prawa i nauk spolecznych Uniwersytetu Stefana Batorego w Wilnie 1919-1939, „Kwartalnik Historii Nauki i Techniki” 61, 2016, nr 2, s. 26. 
Wileński okres w życiu Iwo Jaworskiego pozostałby jednym z dwóch — jeśli nie liczyć okresu krakowskiego — najważniejszych etapów w jego życiu, gdyby nie wydarzenia, które nastąpiły po 1 września 1939 roku (ewentualnie po 15 grudnia 1939 roku). Spowodowały one, że sześć lat później rozpoczął się trzeci etap w jego życiu — wrocławski. Okres wrocławski ${ }^{55}$ i wileński zostały już opisane, pozostał oddzielający je czas II wojny światowej — pod względem naukowym na pewno nie najważniejszy, lecz równie istotny. Będzie trudno go opisać, ponieważ jest on najsłabiej udokumentowany i nie ma już osób, które mogłyby o nim opowiedzieć.

\section{Bibliografia}

Archidiecezjalny Kongres Eucharystyczny, Wilno 1930.

Czapiuk A., Spotkanie historyków w międzywojennym Wilnie. O Powszechnym Zjeździe Historyków Polskich, „Białostockie Teki Historyczne” 8, 2010.

Filaszkiewicz O., Juliusz Bardach - wileńskie lata, [w:] Stefan Ehrenkreutz i historycy prawa okresu dwudziestolecia międzywojennego. W 70. rocznicę śmierci ostatniego Rektora Uniwersytetu Stefana Batorego w Wilnie, red. D. Szpoper, P. Dąbrowski, Gdańsk-Olsztyn 2016.

Gawrońska-Garstka M., Uniwersytet Stefana Batorego. Uczelnia ziem pólnocno-wschodnich Drugiej Rzeczypospolitej (1919-1939) w świetle źródet, Poznań 2016.

Jaworski I., Bibljografia prac Władysława Leopolda Jaworskiego, [w:] Wt. L. Jaworskiego życie i działalność, red. S. Estreicher et al., Kraków 1931.

Jaworski I., Michał Bobrzyński (1849-1935), „Ateneum Wileńskie” 9, 1936.

Jaworski I., Przedmowa, [w:] 50-lecie pracy pisarskiej Marjana Zdziechowskiego, Wilno 1933.

Jaworski I., Studia nad ustrojem miast na prawie niemieckim $w$ Wielkim Księstwie Litewskim w dobie Jagiellońskiej, „Rocznik Prawniczy Wileński” 5, 1931.

Jaworski I., Zagadnienie feudalizmu litewskiego i zachodniego, [w:] Pamiętnik Powszechnego Zjazdu Historyków Polskich w Wilnie 17-20 września 1935 roku, t. 1, Lwów 1936.

Klein E., Koredczuk J., Iwo Jaworski (1898-1959), [w:] Pamięci zmartych Profesorów i Docentów Wydziału Prawa, Administracji i Ekonomii Uniwersytetu Wrocławskiego 1945-2010, red. L. Lehmann, M. Maciejewski, Wrocław 2010.

Koredczuk J., 60-lecie powołania katedr historyczno-prawnych na Wydziale Prawa Uniwersytetu Wroctawskiego, „Prawo” 303, 2007.

Koredczuk J., Powojenna działalność naukowa byłych wileńskich profesorów historii prawa: Iwo Jaworskiego i Seweryna Wystoucha, [w:] Stefan Ehrenkreutz i historycy prawa okresu dwudziestolecia międzywojennego. W 70. rocznicę śmierci ostatniego Rektora Uniwersytetu Stefana Batorego w Wilnie, red. D. Szpoper, P. Dąbrowski, Gdańsk-Olsztyn 2016.

Lietuvos Centrinis Valstybés Archyvas Fond 175, Ap. 1(I)A, nr 55.

LCVA Fond 175, Ap. 1(I)A, nr 805.

LCVA Fond 175, Ap. 1(I)Bb, nr 731.

Łowmiański H., Zagadnienie feudalizmu w Wielkim Księstwie Litewskim, [w:] Pamiętnik Powszechnego Zjazdu Historyków Polskich w Wilnie 17-20 września 1935 roku, t. 1, Lwów 1936.

55 Por. chociażby J. Koredczuk, Powojenna działalność naukowa byłych wileńskich profesorów historii prawa: Iwo Jaworskiego i Seweryna Wystoucha, [w:] Stefan Ehrenkreutz i historycy..., s. 209-221; bądź też inne publikacje tego autora dotyczące dziejów nauki i nauczania prawa we Wrocławiu po II wojnie światowej.

Prawo 325, 2018

(C) for this edition by CNS 
Mieczkowski R., Andrzej Stefan Ehrenkreutz (1921-2008), „Niepodległość i Pamięć” 2009, nr 29. Mycielski A., Chwile czasu minionego, Warszawa 2012.

Odnowienie doktoratu profesora Juliusza Bardacha na Uniwersytecie Jagiellońskim „Czasopismo Prawno-Historyczne" 51, 1999, z. 1-2.

Przeniosło M., Profesorowie wydziału prawa i nauk społecznych Uniwersytetu Stefana Batorego w Wilnie 1919-1939, „Kwartalnik Historii Nauki i Techniki” 61, 2016, nr 2.

Rocznik Uniwersytetu Stefana Batorego w Wilnie 1938-1939, Wilno 1939.

Sprawozdanie z działalności Wydziału Prawa i Nauk Społecznych Uniwersytetu Stefana Batorego w Wilnie za rok akademicki 1934/35, oprac. B. Wróblewski, „Rocznik Prawniczy Wileński” 8, 1936.

Sprawozdanie z działalności Wydziału Prawa i Nauk Społecznych Uniwersytetu Stefana Batorego w Wilnie za rok akademicki 1936/37, oprac. J. Panejko, „Rocznik Prawniczy Wileński” 9, 1938.

Szpoper D., Tarkowski M., Nauczanie prawa na Uniwersytecie Stefana Batorego w Wilnie (19191939), [w:] Wybrane problemy nauki i nauczania prawa, red. E. Kozerska, P. Sadowski, A. Szymański, Opole 2010.

Tarkowski M., Iwo Jaworski - wileński historyk prawa, [w:] Stefan Ehrenkreutz i historycy prawa okresu dwudziestolecia międzywojennego. W 70. rocznicę śmierci ostatniego Rektora Uniwersytetu Stefana Batorego w Wilnie, red. D. Szpoper, P. Dąbrowski, Gdańsk-Olsztyn 2016.

Tarkowski M., Rada Wydziału Prawa i Nauk Społecznych Uniwersytetu Stefana Batorego w Wilnie (1919-1939), „Studia Iuridica Toruniensia” 7, 2010.

Tarkowski M., Wydział Prawa i Nauk Społecznych Uniwersytetu Stefana Batorego w Wilnie w latach 1919-1939, Gdańsk 2015.

Uroczysta promocja doktorów honoris causa Wydziału Prawa i Nauk Społecznych Uniwersytetu Stefana Batorego w dn. 29 maja 1930 r., „Rocznik Prawniczy Wileński” 4, 1930.

Winowski L., Iwo Jaworski, [w:] Uczeni wrocławscy (1945-1979), red. J. Trzynadlowski, Wrocław 1980.

Żukowski P.M., O obsadzaniu katedr historyczno-prawnych w Drugiej Rzeczypospolitej, [w:] Stefan Ehrenkreutz i historycy prawa okresu dwudziestolecia międzywojennego. W 70. rocznice śmierci ostatniego Rektora Uniwersytetu Stefana Batorego w Wilnie, red. D. Szpoper, P. Dąbrowski, Gdańsk-Olsztyn 2016.

Żukowski P.M., Uniwersytet nie tylko polski. Jeden z ostatnich śladów Rzeczypospolitej Jagiellońskiej - Uniwersytet Stefana Batorego w Wilnie — nadal czeka na swoja rzetelna monografie, „Res Gestae" 4, 2017. 4.

„Alma Mater Vilnensis” 1935, z. 12.

„Kurjer Wileński” z dnia 17 maja 1935 r., r. XII, nr 133.

„Rocznik Prawniczy Wileński” 4, 1930.

\section{The Vilnius period in Iwo Jaworski’s life}

\section{Summary}

The Vilnius period in Iwo Jaworski's life, from 1922 until 1939, was one of the most important periods in his life. It began when he became Chair of History of Law in Western Europe at the Stefan Batory University in 1922. It was also associated with the formation of the Faculty of Law and Social Sciences at the University. In 1927 Iwo Jaworski obtained his post-doctoral degree (habilitation) and in 1932 he was made professor. In his research he focused on political and legal questions connected with the French Revolution as well as legal questions concerning the Grand Duchy of Lithuania. In addition to conducting research, he was also active in popularising science, and was an outstanding teacher, whose lectures and seminars were very popular among students. That he was trusted by those around him is evidenced by his participation in several collegiate bodies at

Prawo 325, 2018

(C) for this edition by CNS 
the university and the fact that he supervised several student organisations. The Vilnius period was also extremely important in his private life. It was in Vilnius that he started a family and despite the fact that he moved several times, his home was a place of social gatherings of many of his friends (including people who, like himself, found themselves in Wrocław after the war). Interludes in his life in Vilnius were provided by military training courses which he was called to attend.

Keywords: Chair of History of Law in Western Europe, Stefan Batory University, Faculty of Law and Social Sciences, Vilnius

\title{
Die Vilniusser Zeit im Leben von Iwo Jaworski
}

\author{
Zusammenfassung
}

Die Vilniusser Zeit im Leben von Iwo Jaworski, also die Jahre 1922-1939, gehört zu den wichtigsten Perioden seines Lebens. Diese begann, als er im Jahre 1922 auf den Lehrstuhl für Geschichte des Rechts in Westeuropa an der Stefan-Batory-Universität berufen wurde. Sie war auch mit der Errichtung der Fakultät für Recht und Sozialwissenschaften an dieser Universität verbunden. In diesem Zeitraum, im Jahre 1927, habilitierte sich Iwo Jaworski und im Jahre 1932 erwarb er den Professorentitel. Den Schwerpunkt seines wissenschaftlichen Werkes bildeten die verfassungsrechtlichen Fragen bezogen auf die Französische Revolution und die rechtliche Problematik betreffend das Großfürstentum Litauen. Neben der Arbeit als Wissenschaftler beschäftigte sich Iwo Jaworski auch aktiv mit der Förderung der Wissenschaft. Er war dabei ein ausgezeichneter Didaktiker und seine Vorträge und Seminare erfreuten sich großer Beliebtheit bei den Studenten. Ein Zeichen des Vertrauens ihm gegenüber war seine Beteiligung an kollegialen Organen der Universität und sachliche Leitung einiger Studentenorganisationen. Die Zeit in Vilnius war auch für sein privates Leben wichtig. Dort hat Iwo Jaworski seine Familie gegründet und seine Wohnung, trotz einiger Umzüge, diente stets als ein Treffpunkt für viele mit ihm befreundete Personen (darunter diejenige, die, ähnlich wie er, nach dem Zweiten Weltkrieg nach Wrocław kamen). Die Vilniusser Zeit unterbrachen gelegentliche militärische Schulungen, die er zu absolvieren hatte.

Schlüsselworte: Lehrstuhl für Geschichte des Rechts in Westeuropa, Stefan-Batory-Universität, Fakultät für Recht und Sozialwissenschaften, Vilnius 